\title{
Essentials of Intellectual Capital to Create Higher Education Sustainable Competitive Advantage: Environment Uncertainty as a Moderating Variable in Indonesia Private Universities
}

\author{
Submitted 15/12/20, $1^{\text {st }}$ revision 17/01/21, $2^{\text {nd }}$ revision 19/02/21, accepted 20/03/21
}

\author{
Harry Suharman ${ }^{1}$, Nurul Hidayah ${ }^{2}$
}

\begin{abstract}
:
Purpose: The objective of this paper is to ascertain the influence of intellectual Capital on sustainable competitive advantage and to analyze environmental uncertainties that will strengthen or weaken to achieve of sustainable competitive advantage. Design/Approach/Methodology: To achieve the stated objective, the study used survey research design, with 151 samples from a population of 234 private higher education in Indonesia. A validated questionnaire was used to collect data and structural equation modelling was used to analyze the data.

Findings: Results showed that the intellectual capital has a significant effect on sustainable competitive advantage. Meanwhile, environmental uncertainty has not been shown to strengthen or weaken university's competitiveness.

Practical Implication: The results can be used in efforts to improve the quality of private university in Indonesia and to suggest that intellectual capital management is the key to success and triggers for university value creation and the environmental uncertainty must be faced and anticipated in order to continue sustainable competitiveness.

Originality/Value: This study is an original study and conducted interviews to obtain information the condition of private university and describe how intellectual capital can create sustainable competitive advantage and still must pay attention on the effect of environment uncertainty.
\end{abstract}

Keywords: Higher education, intellectual capital, sustainable competitive advantage, environment uncertainty.

JEL codes: M20, M41.

Paper Type: Research Article.

\footnotetext{
${ }^{1}$ Department of Economic and Business, Universitas Padjajaran Bandung, Indonesia, ORCID: 0000-0003-0787-0730, e-mail: harry.suharman@unpad.ac.id

${ }^{2}$ Department of Economic and Business Universitas Mercu Buana Jakarta, ORCID: 00000002-0680-5681, e-mail: nurul.hidayah@mercubuana.ac.id
} 


\section{Introduction}

Globalization and business competition are important points that must be considered by education institutions. University competitiveness is closely related to the global free-market economy. The combined impact of globalization and global knowledge economy development will be faced by higher education today because it creates a global competitive force and connection with the global free-market economy (Rust and Kim, 2012). Indonesia has the potential for large purchasing power, needs to be supported by the quality of human resources. This support is through the provision of a skilled and trained workforce (Schwab, 2015). The provision of skilled and trained human resources is an important factor for achieving a sustainable competitive advantage (Chuang, Liu, and Chen, 2015). In the era of globalization, to improve the competitiveness of the economy, one of the ways by determining its main strategy is to improve the quality of higher education. The Indonesian government has a sustainable development agenda (Sustainable Development Goals) for 2030, consists of seventeen goals where a fourth of the agenda is to ensure proper quality education for the community.

University, as a part of higher education, has a role in providing quality human resources. Universities are hoping to develop the student into a graduate who has the competence and ability to be competitive in the labour market. Based on the 2018 Global Competitiveness Report, which was taken from the World Economic Forum (WEF), Indonesia' economic competitiveness index is ranked 45th with a score of 64.9 points, and the index is still low compared to higher education in ASEAN Universities in Indonesia especially private universities have to improve the ability to grow and develop their competencies. The problem that always faces higher education includes quality of education, relevance, and competitiveness of education. One of the leading main causes of the problems is the low competitiveness of private universities to increase human resources quality, especially increasing the lecturers' competitiveness. Meyer and Maier (2012) state that how to improve the higher education quality, it must be started from human resources' quality that will achieve sustainable competitive advantage. This is certainly in accordance with the goals of Indonesia's SDGs, as described above. Rosser's study (2018) explains that the cause of the inadequate quality of education in Indonesia is seen from the inability of domestic university graduates to compete with foreign university graduates. Higher education is not only producing human resources but improving its quality is important to pay attention because universities have a role in growing and producing quality talent in society (Zhang and Guo, 2014).

Intellectual capital is an intangible asset. It is role in defining the value of a university. Universities prioritize their investment in teaching, research, and human resources, with the primary goal of producing and transferring knowledge (Leitner and Warden, 2014; Sánchez et al., 2009). Higher education also must manage intellectual capital practices because it is an essential factor to improving 
sustainability, while the other factors are reputation, competitiveness, and wealth (Matos et al., 2019). Intellectual capital is resources on which the organization relies in the broadest sense, including human Capital, structural Capital, and relational Capital. Universities have human capital consist of the knowledge of lecturers, researchers, students, and administrative staff. Simultaneously, the governance principles, organizational routines, procedures, systems, university culture, databases, publications, and intellectual property are structural capital elements. At the same time, universities need a relationship with stakeholders, that is the relational Capital. Relational Capital describes all the university activities related to industries, non-profit sectors, public authorities, local government, and society as a whole.

Sadalia et al.' (2017) study concludes that no significant impact of human Capital on competitive advantage, but structural Capital and relational Capital have a positive and significant impact on competitive advantage. In comparison, research by Alnidawi et al. (2017) concludes that there was a positive impact of human resources on the creation of competitive advantage. The existence of competitive advantage based on human resources is a factor for creating organizational sustainability and its success. Besides the intellectual Capital, universities also pay attention to environmental factors, both internal and external, intellectual Capital will affect the higher education competitive advantage.

The rapidly changing internal and external environment is an uncertainty facing higher education. Oliver and Parrett (2018) explain that the causes of environmental uncertainty are increased technology and innovations, leading to global changes. Managers must recreate various kinds of creative and more holistic competitive strategies to solve the problems. Environmental uncertainty is indicated by the lack of universities' response to changes in the technological environment and innovation as well as economic globalization (Altbach and Hazelkorn, 2018). Pasban and Nojedeh (2016) conclude that human skills are an important factor at all levels of management that can create customer satisfaction and increase an organization's competitive advantage. Abdelkader (2017) study has resulted that no moderation effect of environmental uncertainty on the relationship between Information Technology and competitive advantage.

\section{Literature Review}

\subsection{Intellectual Capital and Sustainable Competitive Advantage}

Universities can generate knowledge (research), transmit knowledge (teaching), employ knowledge workers, and measure, manage, and report. Research and teaching and employing knowledge workers are the intellectual capital concept that is university's core business named knowledge transfer (Veltri and Schaffhauser, 2014; Sánchez and Castrillo, 2009). Universities produce knowledge through three activities, namely teaching, research, and community service. Intangible assets in the 
form of knowledge embedded in the universities become a significant key because knowledge is the main output and input. University provides activity research from the results of an investigation, research publication, teaching, students trained, and stakeholders relationships (Ramirez and Gordillo, 2014). The combination of knowledge production and the development of a relationship within a community is intellectual Capital.

Universities in many countries have carried out internal analyses of their organizations by increasing their intellectual Capital due to increased competition. Hazline and Zubaidah (2009) and Jaradate et al. (2012) noticed that universities could manage intellectual Capital as a competitive advantage source. Fazlagic and Skikiewicz (2014) explain that Intellectual Capital is a company's ability to create knowledge by innovating, implementing new initiatives, and building positive relationships with stakeholders. Secundo et al. (2017) stated that activity in intellectual Capital includes activity teaching and research, which will increase the university's competitiveness and stimulate innovation through the transfer of knowledge and technology to industry and society. The important and fascinating issue because of the intangible nature of knowledge, although knowledge is not easy to measure.

Kong and Prior (2008) conclude that the important resource as intellectual capital had been recognized by the organization to develop sustained competitive advantages. While Barney (1991) states that an organization has a competitive advantage if the condition in which competitors are incapable of duplicating its competitive strategies implemented by the company and competitors are not able to obtain the benefit that the company acquired. Competitive advantage does not embed in physical assets and financial capital but more focused on unique intellectual resources. Research by Sharabati et al. (2010), Khalique et al. (2011), and Wang (2010), state that intellectual Capital is playing a significant contribution. Intellectual capital will create excellence within innovation, creativity, and organizational performance related between capability and organizational intellectual capital (Marr and Roos, 2005)

\section{H1: Intellectual Capital significantly influence Sustainable Competitive Advantage.}

\subsection{Intellectual Capital, Environment Uncertainty and Sustainable Competitive Advantage}

Beketova (2016) explains that policies in the face of change must support the challenge of achieving quality education. These changes are related to environmental changes consisting of macro and microenvironments, such as globalization, technological advances, demographic changes, information revolution, distance lectures, funding, competition between universities, quality of teaching, and quality of service. Changes in the internal and external environment that caused 
environmental uncertainty faced by the education sector are getting more involved with increasing competition in the education services market. The study of Oliver and Parrett (2018) explains that the causes of environmental uncertainty are increased technological advances and innovations, leading to global changes in the world economy. For this reason, organizational managers must re-create various kinds of creative and more holistic competitive strategies to overcome problems that occur. Arises from the implementation of strategies that have been made previously.

One of the strategies that can help to deal with uncertainty is to optimize Intellectual Capital. Brian et al. (2016) concluded that universities must identify potential volatility, uncertainty, complexity, and ambiguity that affect competitive advantage. The main threats identified to the higher education sector include the uncertain mix of technology, economic, and political trends. Secundo et al. (2017) explained that universities' important role reflected in a knowledge-based economy that stimulate innovation by transferring new knowledge and technology. Therefore, universities need human resources with qualified intellectual Capital to create the ability to compete with their competitors.

\section{H2: Environment Uncertainty mediates the influence of Intellectual Capital on Sustainable Competitive Advantage.}

\section{Methodology}

The method used in this research is descriptive and causal-explanatory methods to test the research hypothesis. Variables need to be broken down into observable characteristics to reduce the level of abstraction, it is called the operationalization of research variables (Sekaran and Bougie, 2013). The operationalization of the variables in this research consisted of three variables: Intellectual Capital consists of three dimensions namely human Capital, Structural Capital and Relational Capital, Environment Uncertainty consist of three dimensions, political uncertainty, technology uncertainty, and market competitive uncertainty, while the dimensions of Sustainable Competitive Advantage including, Innovation, Market, Social and Universities Financing.

The population of the research is all the private universities in Indonesia. The selection of private universities is because there are more private universities than Indonesian public universities, where private universities have different abilities to compete with other universities. This research used a non-probability sampling technique and purposive sampling criteria to meet the sample criteria, which the sample was derived from the population of Indonesian private universities that have very good (B) accreditation and listed in the center of Science, Technology, and Higher Education. Selected private universities were sent the online questionnaire where the respondents were university leaders consisting of the chancellor and other officials at the Dean, study program levels, etc. 254 questionnaires distributed by email, and the total returned were 151 questionnaires, which means the response rate 
was 59.4\%. The structural equation modelling (SEM) Partial Least Square (PLS) used as a statistical tool to analyze and interpret the result of the hypothesis test consisting of the outer model (to test validity and reliability) and inner model to the evaluation of structural models or hypothesis.

\section{Findings and Discussions}

\subsection{Measurement Model}

The first step in reflective measurement model assessment involves examining the indicator loadings. Loading factors above 0.50 are recommended, as they indicate that the construct Intellectual Capital, Environmental Uncertainty, and Competitive Sustainable Advantage explains more than 50 percent of the indicator's variance, thus providing acceptable item reliability.

Table 1. Loading Factors

\begin{tabular}{|l|l|l|l|}
\hline & EU & IC & SCA \\
\hline E & 0.791 & & \\
\hline E & 0.815 & & \\
\hline E & 0.809 & & \\
\hline E & 0.869 & & \\
\hline E & 0.787 & & \\
\hline E & 0.829 & & \\
\hline E & 0.635 & & \\
\hline IC ${ }^{*} \mathrm{EU}$ & 0.764 & & \\
\hline I & & & \\
\hline I & & 0.57 & \\
\hline I & & 0.68 & \\
\hline I & & 0.56 & \\
\hline I & & 0.84 & \\
\hline I & & 0.83 & \\
\hline I & & 0.67 & \\
\hline S & & 0.79 & \\
\hline S & & & 0.832 \\
\hline S & & & 0.775 \\
\hline S & & & 0.837 \\
\hline S & & & 0.834 \\
\hline S & & & 0.546 \\
\hline & & & 0.642 \\
\hline
\end{tabular}

Source: Own study.

Table 1 show the Outer Model that examining the indicator loadings Intellectual Capital (IC), Environment Uncertainty (EU) and Sustainable Competitive Advantage (SCA). The result tests of all indicators above 0.50 are recommended. This mean that the constructs of IC, EU, and SCA are reliable. 
The second step is assessing internal consistency validity and reliability. Another method to test the validity is convergent validity (Average Variance Extract), if the value is above 0.5 the variable construct is valid while reliability values between 0.60 and 0.70 are considered acceptable in the research. Higher values generally indicate higher levels of reliability.

Table 2. Reliability and Validity

\begin{tabular}{|l|c|r|l|l|}
\hline & Cronbach's Alpha & rho_A & $\begin{array}{l}\text { Composite } \\
\text { Reliability }\end{array}$ & $\begin{array}{l}\text { Average } \\
\text { Variance } \\
\text { Extracted } \\
\text { (AVE) }\end{array}$ \\
\hline EU & 0.913 & 0.925 & 0.929 & 0.623 \\
\hline IC & 0.840 & 0.864 & 0.888 & 0.517 \\
\hline SCA & 0.845 & 0.872 & 0.885 & 0.567 \\
\hline
\end{tabular}

Source: Own study.

Table 2 shows the Average Variance Extract (AVE) values of Environment Uncertainty (.623), Intellectual Capital (.517), and SCA (.567) indicate that all constructs' variables have achieved the minimum threshold value and established a high level of convergent validity. Cronbach's Alpha shows all variables .913 for Environment Uncertainty, .840 for Intellectual Capital, and .845 for SCA, also the value of C.R. above 0.70 , the result shows that the research instrument is reliable to measure complex affective domains for all the constructs.

\subsection{Structural Model}

The next test of hypothesis is the inner model or structural model test to see the relationship between constructs and the significance value and the $r$ square value as in the following Table 3:

Table 3. $R$ Square

Source: Own study.

\begin{tabular}{|l|l|}
\hline & R Square \\
\hline SCA & 0.572 \\
\hline IC & - \\
\hline IC*EU SCA & - \\
\hline
\end{tabular}

Table 3 shows that the $\mathrm{R}$ square value of 0.572 , the variability of Sustainable Competitive Advantage (SCA) construct can be explained by Intellectual Capital construct at $57,2 \%$. 
Table 4. Path Coefficient

\begin{tabular}{|c|c|c|c|c|c|}
\hline & $\begin{array}{l}\text { Origin } \\
\text { al } \\
\text { Sample } \\
\text { (O) }\end{array}$ & $\begin{array}{l}\text { Samp } \\
\text { le } \\
\text { Mean } \\
(\mathrm{M})\end{array}$ & $\begin{array}{l}\text { Standar } \\
\mathrm{d} \\
\text { Deviatio } \\
\text { (STDEV) }\end{array}$ & $\begin{array}{l}\mathrm{T} \\
\text { Statistics } \\
(\mathrm{O} / \mathrm{STDEV})\end{array}$ & $\begin{array}{c}\mathrm{P} \\
\text { Values }\end{array}$ \\
\hline EU $\rightarrow$ SCA & 0.352 & 0.363 & 0.114 & 3.103 & 0.002 \\
\hline IC $->$ SCA & 0.734 & 0.731 & 0.065 & 3.700 & 0.000 \\
\hline $\begin{array}{l}\text { Moderating Effect } 1 \text { - } \\
>\text { SCA }\end{array}$ & 0.003 & -0.006 & 0.048 & 0.065 & 0.948 \\
\hline
\end{tabular}

Source: Own study.

Table 4 explains that the intellectual capital construct has a significant influence on sustainable competitive advantage with P-Value $0.000(<0.05)$ and T Statistic 3.700 (>1.96). Universities need to develop higher skills; all university members (lecturers and students) must have sufficient knowledge, information, innovation, and creativity to increase satisfaction and create a competitive advantage for the organization. This research support Secundo et al. (2017) study concluded that universities have an important role in a knowledge-based economy to stimulate innovation by transferring new knowledge and technology increasing the ability to compete in a country.

Environment Uncertainty has significant influence on sustainable competitive advantage with P-Value $0,002(<0.05)$ and T Statistics $3.103(>1.96)$. The result of this also supports the opinion of Dreyer and Grønhaug (2004), to maintain and improve its competitiveness, the organization must exploit opportunities and neutralize various uncertainties and threats in its competitive environment. Environmental uncertainty is one of the company's threats but cannot be easily avoided. At the same time, Torres and Schugurensky (2002) conclude that changes in the political system caused universities to be forced and more independent of increasing efficiency, management, and giving more influence on society. While the construct of interaction between Intellectual Capital (I.C.) and Environmental Uncertainty (E.U.) does not affect Sustainable Competitive Advantage (SCA) at PValue $0.9548(>0.05)$ and T Statistic $0.065(<1.96)$, it can be concluded that there is no moderation effect. Environment Uncertainty is a condition of the university's inability to know what will be faced in the future. University must be anticipated by preparing a strategy to minimize the risks that will occur. Environment Uncertainty is not a factor that will increase or decrease the superiority of university competition but must be faced.

\section{Conclusion}

The main purpose of this study is to explore the importance of intellectual capital as a source of sustainable competitive advantage for university compete in the world. Tan et al. (2008) state that I.C. is reflected by a strategic perspective 
Essentials of Intellectual Capital to Create Higher Education Sustainable Competitive

Advantage: Environment Uncertainty as a Moderating Variable in Indonesia Private

Universities

390

in which intellectual Capital becomes the key role in the creation of knowledge.

I.C. is the only strategy that gives an organization a competitive edge, sustainable, how fast it can know something new. Intellectual Capital produces from the knowledge as a source of competitive advantage. This research develops intellectual Capital as a university strategy to achieve competitive advantage and aims to create graduates who can compete in the labour market. Universities using I.C. to create knowledge and manage knowledge become an important asset of a knowledge-based economy. Herremans et al. (2010) suggest that managers' structure whose control systems appropriate will develop I.C. capabilities and the systems can reduce internal uncertainty regarding human, structural, and Relational Capital.

\subsection{Limitations and Future Research Direction}

Limitation of this research is the use of IC, EU that influence SCA. There are other factors that can influence the sustainable competitive university. Therefore, researchers must be encouraged for future research with other variables that are related to higher education sustainable competitive institution.

\section{References:}

Abdelkader, Berrich, Abed, Benkaddour. 2016. The effect of information technology on competitive advantage of firm: The role of environmental uncertainty. The International Journal of Management Science, and Information Technology (IJMSIT), ISSN 1923-0273, NAISIT Publishers, 22, 16-39.

Altbach, Philip, Hazelkorn, Ellen. 2018. Measuring Education Quality in Global Ranking: What is the Likelihood? International Higher Education, No 95. https://doi.org/10.6017/ihe.2018.95.10721.

Alnidawi, Abdul, Azeez Badir, Abdul Sattar, Husien Alshemery, Manal Abdulrahman. 2017. Competitive Advantage Based on Human Capital and Its Impact on Organizational Sustainability: Applied Study in Jordanian Telecommunications Sector. Journal of Management and Sustainability, 7(1), 64-75.

Brian, Sterart, Khare, Anshuma, Schatz, Rod. 2016. Volatility, Uncertainty, Complexity and Ambiguity in Higher Education. Springer International Publishing.

Chuang, Huan-Ming, Liu, M.J., Chen, Y.S. 2015. The Effects of Human Resource Capability and Internal Customer Satisfaction on Organizational Effectiveness. International Journal of Distributed Sensor Networks. 10.1155/2015/835194.

Cooper, D.R., Emory, W.C. 1997. Metode Penelitian Bisnis. Erlangga, Jakarta.

Dreyer, B., Kjell, G. 2004. Uncertainty, Flexibility, and Sustained Competitive Advantage. Journal of Business Research, 57(5), 484-494.

Hazline, H., Zubaidah, Z.A. 2009. Board structure and corporate performance in Malaysia. International Journal of Economic and Finance, 1(1), 150-164.

Herremans, I.M., Isaac, R.G., Kline, T.J.B., Nazari, J.A. 2010. Intellectual Capital and Uncertainty of knowledge: Control by Design of the Management System. Journal of Business Ethics, 98(4), 627-640. 10.1007/s10551-010-0642-7. 
Jaredite, O.M., Al-Samra lie, F.A., Abdallah, N.A. 2012. Intellectual capital and its role in achieving competitive advantage: a field study for the Jordanian income tax service. European Journal of Science Research, 69(3), 399-415.

Kong, E. 2008. An intellectual capital perspective of non-profit strategy: a strategic advantage conceptual framework. In: 3rd International Conference on Contemporary Business (ICCB 2006): Engagement and Change: Managing in a Free Trade Environment, 21-22 Sept, Leura, Blue Mountains, NSW, Australia.

Leitner, K.H., Elena, S., Fazlagic, J., Kalemis, K., Marinaitis, Z., Secundo, G., Sicilia, M.A., Zaksa, K. 2014. A Strategic Approach for Intellectual Capital Management in European Universities, Guidelines for Implementation. UEFISCDI Blueprint Series.

Matos, F., Vairinhos, V., Maurício, P., Leif, S. 2019. Introduction. In Intellectual Capital Management as an Indicator of Sustainability. Springer International Publishing: Cham, Switzerland, 1-10.

Meyer, M., Maier, F. 2012. Corporate Governance in Non-profit Organizations: Understandings and Future Perspectives. Zeitschrift für Wirtschafts- und Unternehmensethik, 13. 10.5771/1439-880X-2012-1-9.

Oliver, J.J., Parrett, E. 2018. Managing Future Uncertainty: Re-Evaluating the Role of Scenario Planning. Business Horizons, 61, 2, 339-35. Available at SSRN: https://ssrn.com/abstract=3127428.

Pasban, Moh., Sadegheh, N. 2016. A Review of the Role of Human Capital in the Organization. Procedia - Social and Behavioral Sciences, 230.

Ramirez, Y., Gordillo, S. 2014. Recognition and measurement of intellectual capital in Spanish universities. Journal of Intellectual Capital, 15, 1, 173-188.

Rosser, A. 2018. Beyond access: Making Indonesia 's education system work. Lowy Institute, Victoria State Government.

Rust, V.D., Kim, S. 2012. The Global Competition in Higher Education. World Studies in Education, Vol 3, No 1, 5-20.

Schwab, K. 2018. The Global Competitiveness Report 2018. Insight Report. World Economic Forum, 91-93.

Sánchez, M.P., Elena, S., Castrillo, R. 2009. Intellectual capital dynamics in universities: a reporting model. Journal of Intellectual Capital, 10, 2, 307-324.

Sadalia, I., Irawati, N., Syafitri, I. 2017. The Influence of Intellectual Capital on Competitive-on-Competitive Advantage on Universities in Medan City. Advances in Economic Business and Management Research, 46. Atlantis Press.

Secundo, G., De Beer, C., Cornelius, S.L., Schutte, Giuseppina, P. 2017. Mobilising Intellectual Capital to Improve European Universities' Competitiveness: The Technology Transfer Offices' Role. Journal of Intellectual Capital, 18(3), 607624.

Sekaran, U., Bougie, R. 2014. Research method for business. John Wiley \& Sons, Inc.

Tan, H.P., Plowman, D., Hancock, P. 2008. The evolving research on intellectual Capital. Journal of Intellectual Capital, 9(4), 585-608.

Torres, C.A., Schugurensky, D. 2002. The political economy of higher education in the era of neoliberal globalization: Latin America in comparative perspective. Higher Education. 